\title{
Toxicological Evaluation of Drinking Water Sources in Some Rural Communities in Southern Nigeria after Mycofiltration Treatment
}

\author{
Daniel Olorunfemi ${ }^{1 *}$, Uruemu Efechuku², Janice Esuana ${ }^{3}$ \\ 'Department of Environmental Management and Toxicology, Faculty of Life Sciences, \\ University of Benin, Benin City, Nigeria \\ ${ }^{2}$ Environmental Science Unit, Faculty of Life Sciences, University of Benin, Benin City, Nigeria \\ ${ }^{3}$ Department of Science Laboratory Technology, Faculty of Life Sciences, University of Benin, Benin City, Nigeria
}

Received: 14 October 2014

Accepted: 11 December 2014

\begin{abstract}
Available domestic water in many communities in Nigeria is increasingly polluted on a daily basis. A major issue of national interest is how these polluted drinking water sources could be fully assessed and mitigated. In this study, mycofiltrated domestic water samples obtained from hand-dug wells and boreholes in six rural communities in Ughelli South Local Government Area of Delta State, Nigeria were evaluated for potential cyto-genotoxicity using the Allium cepa bioassay. Data obtained from physicochemical analysis after a 24hour mycofiltration treatment of the water samples revealed significant $(\mathrm{p}<0.05)$ reduction/total elimination of heavy metals and microbial load in the samples. Results obtained from the 96-hour macroscopic evaluation of $A$. cepa showed that compared to onions grown in untreated samples, significant $(\mathrm{p}<0.05)$ reduction in root growth inhibition occurred in bulbs cultivated in mycofiltrated samples. Root tips of $A$. cepa processed for cytological studies by the aceto-orcein squash technique after exposure to the water samples for 48 hours also showed significant $(p<0.05)$ reduction in chromosomal aberrations in onion bulbs grown in mycofiltrated samples. These findings show that mycofiltration technique is an efficient and affordable technology for toxicity reduction in drinking water sources available for rural dwellers in developing countries.
\end{abstract}

Keywords: domestic water, mycofiltration, Allium cepa assay, physicochemical analysis, microbial load

\section{Introduction}

Water is essential for human existence, and its importance for individual health as well as the well-being of a nation cannot be overemphasized. Fresh water represents the main sources of safe water for household use, sustainable development, and human survival. They comprise water from lakes, hand-dug wells, taps, boreholes, streams, rivers and their plains, wetlands, and those available in

*e-mail: udanfem@gmail.com underground reservoirs, making them unavoidable for the evolution of society and civilization [1].

In spite of the considerable investments of the Nigerian government in water supply programs, over $52 \%$ of its citizens have no access to potable water [2]. The fresh water sources available to the local inhabitants are either unsafe or difficult to obtain. In some instances women and children need to walk for hours to fetch ordinary drinking water. An estimated 140 million people are continuously drinking water containing all kinds of germs, heavy metals, bacteria, and dust particles capable of causing various diseases [3]. 
There has been a proliferation of wells and boreholes in recent times, but in spite of this, the joint report on water and sanitation by WHO/UNICEF reveals that Nigeria and many other Sub-Saharan African countries are lagging behind in achieving the millennium development goals and targets set for water and sanitation [4]. Although the country is blessed with abundant water resources, governments at all levels have not been able to successfully harness these resources to ensure sustainable and equitable access to safe, adequate, improved, and affordable water supply and sanitation to the populace [5].

The Niger Delta region of Nigeria is naturally endowed with abundant natural resources, especially water, oil, and gas. Despite the availability of fresh water, the region has been struggling with an acute potable water shortage since the 1980s. Deterioration of water quality in the coastal areas due to salt water intrusion into the freshwater aquifer has become a major concern. The environmental problem in the region poses more threats to life than poverty. Presently, statistics show that water available to individuals declined from 18.91 in 1986 to less than 101 per day among 50\% of the urban population [6].

The Niger Delta area is endangered by gas faring and oil pollution. Production of oil and gas is usually accompanied by substantial discharge of wastewater in the form of brines. Constituents of brines include sodium, calcium, ammonia, boron, trace metals, and high total dissolved solids (TDS). Even rainwater is no longer fit for human consumption due to the contamination of rain (acid rain) and groundwater by the activities of the Nigerian Liquefied Natural Gas Company (NLNG) in Bonny due to gas flaring [7]. Aside from the other consequences of land encroachment, loss of farmlands and wildlife, deforestation and health issues suffered in these communities result from NLNG operations [8]. The residents of the Niger Delta region are faced with an acute problem of drinking water shortage, forcing them to get their domestic water supply from rivers, hand-dug wells, and rainwater harvesting. In a study conducted in 2010, high amounts of particulate matter in their sources of water soon after every down-pour even as claims have been made that the high acidity of the region's rainwater is negatively impacting its river and well water sources linked to the intrusion of acid rain which is precipitated by the influence of the unabated gas flares in the region [9].

Furthermore, many communities in the Niger Delta are facing an acute shortage of portable water because of the surrounding expanse of seawater and tidal creeks. An increase in population in these areas and the resulting increase in groundwater consumption has added to the problem as seawater intrudes further inland in response to pumping. In a recent study, the quality and suitability of boreholes and wells in Okwagbe Community of Delta State, Nigeria were found to be seriously affected due to the high level of turbidity, hardness, and iron in the water [10], making them unsafe for domestic purposes. Other external influences such as tides and recharge events cause changes in the saline/fresh water interface [11].
The major issues of national and international interest are how these water pollution problems could be fully assessed and mitigated. Mycofiltration, a very similar process to mycoremediation, is the use of mycelial mats to filter toxic waste and microorganisms from polluted water. Mycofiltration membranes have been applied to filter pathogens including protozoa, silt, chemical toxins, bacteria, and viruses [12]. The white-rot fungi or their enzymes are able to transform and mineralize; in vitro or in vivo, many environmental organo-pollutants [13]. The use of the fungus Pleurotus tuberregium for the scavenging of heavy metals from aqueous effluents at low $\mathrm{pH}$ and economic treatment of $\mathrm{Cd}^{2+}$ and $\mathrm{Se}^{4+}$ ions has been suggested $[14,15]$.

Since the complexity of contaminated water makes it almost impossible to carry out a hazard assessment based on chemical and microbial analysis alone [16], a comprehensive approach involving the use of plants as standard bioassays alongside physicochemical analysis and other animal tests has been advocated as it has an added advantage [17]. Among the seven plant bioassays reviewed by the US Environmental Protection Agency is Gene-Tox program in 1980, the Allium root tip chromosome aberration assay was one of the protocols adopted and standardized by the International Program on Plant Bioassays (IPPB) for monitoring or testing environmental pollutants, which is currently in operation under the auspices of the United Nations Environment Program (UNEP) $[18,19]$.

Allium cepa L. is very suitable for genotoxic studies. Spontaneous chromosomal damages rarely occur. In addition, the root growth dynamics are sensitive to the pollutants, the mitotic phases are very clear in the onion, it has a stable chromosome number, there is diversity in the chromosome morphology and it has clear and fast response to the genotoxic substances, so that, this test has become well established for the evaluation and determination of the genotoxic substances in various contaminated environments, including drinking water sources [20].

Its use was recommended as early as in the 1970's by the Royal Swedish Academy of Science and later by the Gene-Tox program [21]. Cytogenotoxicity screening of polluted water using the $A$. cepa bioassay serve as perfect monitoring systems for the detection of environmental chemicals that may pose genetic hazards in living organisms. The test shows excellent correlation with animal tests in vivo, which can be extrapolated to humans with reliability [22] and has been used in previous studies to assess the cytotoxicity of domestic water sources [23-26].

In light of the above, this study undertook the bioremediation of contaminated drinking water samples in some rural communities in Ughelli South Local Government Area of Delta State, Nigeria using mycelial mats of whiterot fungi, Pleurotus tuberregium. The A. cepa phytogenotoxicity bioassay was then used to evaluate the effectiveness of the mycofitration bioremediation technology in reducing/removing pollutants from contaminated drinking water sources. 


\section{Materials and Methods}

\section{Study Site}

Drinking water samples from boreholes, rivers, and hand-dug wells were collected from six communities in Ughelli-South Local Government Area of Delta State of Nigeria for the study (Fig. 1). The communities in UghelliSouth were Esaba (US1), Ophorigbala (US2), Owahwa (US3), Iwhreogun (US4), Otuwoama (US5), and Okwagbe (US6).

\section{Collection and Analysis of Water Samples}

The water samples for the study were collected in March, 2013 from rivers, wells and boreholes. Water samples from rivers, and wells were collected at different depths from three random points within the water body in a triangular equilibrium far away from tall buildings and trees using a clean plastic basin. The samples were filtered using filter paper with a pore size of $5 \mu \mathrm{m}$ before analysis. For the borehole, sampling protocols described by Claasen [27], Barcelona et al. [28], and APHA [29] were slightly modified during sampling collection. The nozzles of the boreholes were swabbed with cotton wool soaked in $70 \%$ (v/v) ethanol and flamed for $2 \mathrm{~min}$. Water samples were pumped to waste for $1 \mathrm{~min}$ and then collected in previously washed and sterilized plastic containers. In both cases, samples were taken aseptically into plastic containers and kept in an ice chest and stored in the refrigerator at $4^{\circ} \mathrm{C}$ and analyzed within 24 hours of collection. The pHs of the samples were taken in situ using a Suntex ${ }^{\circledR}$ SP-707 (Taipei, Taiwan) portable pH meter.
The water samples were analyzed for eleven metals, namely: lead, copper, cadmium, chromium, iron, zinc, nickel, manganese, aluminium, cobalt, silver, and nickel according to standard analytical methods [29, 30] using Perkin Elmer A Analyst 100 atomic absorption spectrophotometer (AAS). The metal standards were prepared to known concentrations, labeled, and kept inside plastic bottles that were pre-cleansed with concentrated nitric acid and distilled water. For microbial analysis, the techniques employed were the estimation of total heterotrophic bacteria (THB) by plate count technique and estimation of coliform bacilli by most probable number MPN presumptive test [29].

\section{Mycofiltration Procedure}

Maize cobs were collected from local corn sellers in Iyowa village near Benin City $\left(6^{\circ} 15^{\prime} \mathrm{N}, 5^{\circ} 25^{\prime} \mathrm{E}\right)$ and milled to dust particles, and then sundried to constant weight to reduce moisture content. For the preparation of the substrate, $77 \%$ of the unfermented maize cob dust was supplemented with $20 \%(\mathrm{w} / \mathrm{v})$ wheat bran, $1 \%(\mathrm{w} / \mathrm{v})$ granulated sugar, $1 \%(\mathrm{w} / \mathrm{v})$ calcium sulphate, and $1 \%(\mathrm{w} / \mathrm{v})$ calcium carbonate. These were mixed properly with water, covered with tarpaulin and allowed to compost for seven days. To ensure homogenous fermentation, the substrate was mixed by turning every $48 \mathrm{~h}$. The substrate was thereafter loaded into bags $(15 \times 30 \mathrm{~cm})$ and sterilized by steaming for 3 hours to reduce contaminants, after which it was allowed to cool in a sterile room. After cooling, the substrate was inoculated at the centre with a spawn of Pleurotus tuber-

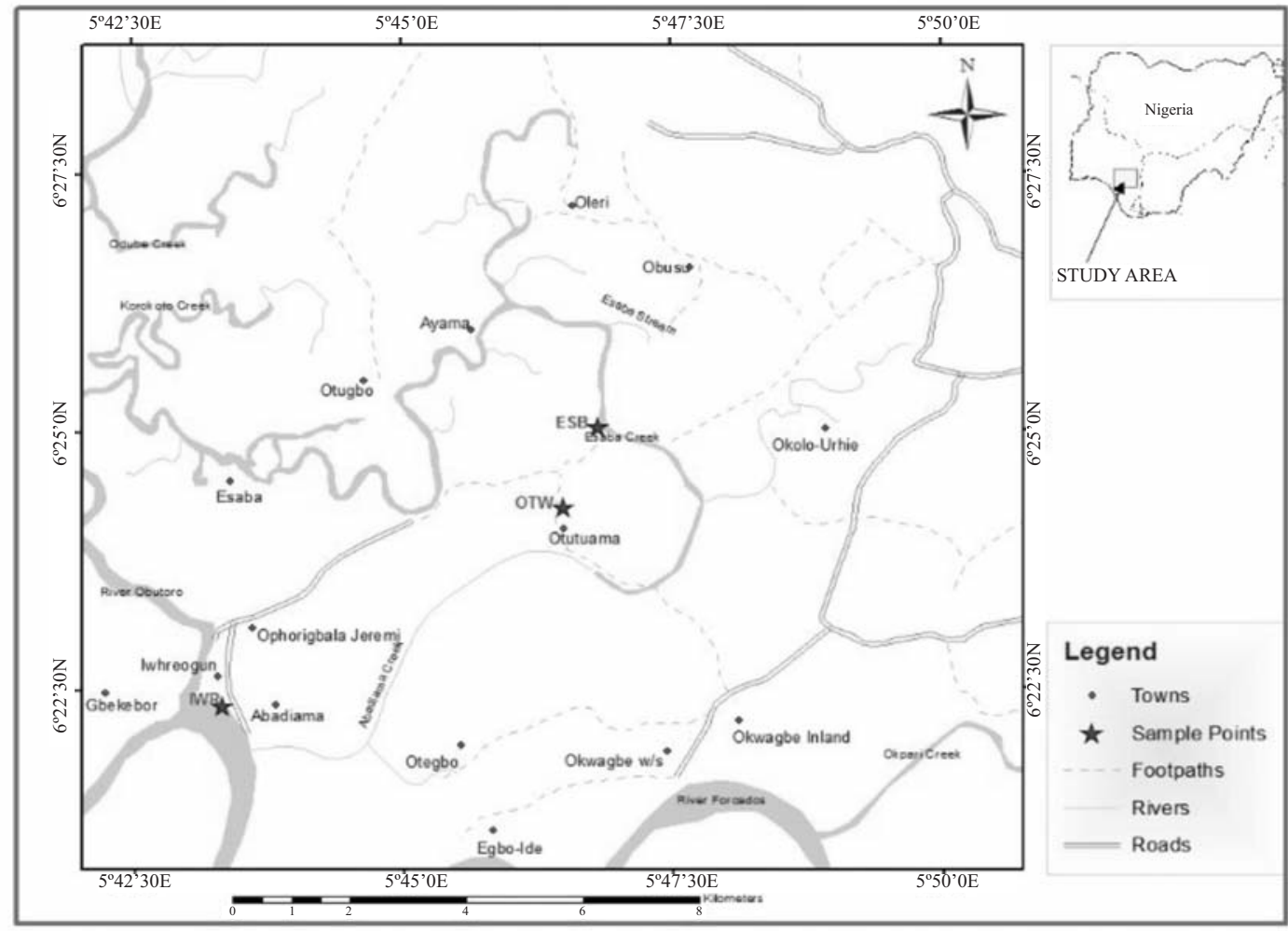

Fig. 1. Map of Ughelli South Local Government Area and environs showing location of sample collection. 
regium and allowed to incubate at ambient temperature $\left(26 \pm 2^{\circ} \mathrm{C}\right)$ until it was fully colonized by the mycelium of the mushroom.

The colonized substrate, which has a hollow made in the middle of it, was put in a perforated bowl and the collected drinking water samples under investigation were separately filtered through the mycelium-permeated maize cob dust substrate.

\section{The Allium Test}

The experimental plant used in this study, Allium cepa L., is commonly known as onion. This variety of Allium species was preferably used for the study because it is commonly grown in the country. Equal-sized onion bulbs $(2 \mathrm{n}=$ 16) were purchased from a local market in Benin City, Edo State $\left(6^{\circ} 15^{\prime} \mathrm{N}, 5^{\circ} 25^{\prime} \mathrm{E}\right)$, and the same batch was used throughout. They were sun-dried for 2 weeks while the mouldy ones or those that were shooting green leaves were all discarded. Their outer scales were carefully removed, without tampering with the primordial root ring.

For evaluating root growth inhibition, seven onion bulbs were utilized for each sachet water sample. The base of each of the bulbs was suspended on the water samples and control inside $100 \mathrm{ml}$ beakers containing about $75 \mathrm{ml}$ of the water sample at $27 \pm 1^{\circ} \mathrm{C}$ in the dark for $96 \mathrm{~h}$. The negative control was tap water obtained from the water factory of UNIBEN Enterprises, University of Benin, Ekenhuan Campus, Benin City. The tap water was pollutant-free and ascertained to be of good quality with a $\mathrm{pH}$ of around 7, relatively high hardness $(\mathrm{Ca}+\mathrm{Mg}=50-70 \mathrm{mg} / \mathrm{l})$, and free from any chlorine compounds and toxic ions as suggested by Fiskesjö [31]. Test samples were changed daily and at the end of the exposure period, 20 root lengths with the best growth were removed with forceps from each of five onions per water sample and measured using a meter rule. From the weighted averages for each sample, the percentage root growth inhibition in relation to the negative control was calculated.

For evaluation of the induction of chromosomal aberration, five onion bulbs were suspended in the water samples and the control for 48 hours. The root tips from the bulbs were cut and fixed in ethanol:glacial acetic acid (3:1, v/v) inside universal bottles and kept at $4^{\circ} \mathrm{C}$ for 24 hours before use. The already fixed root tips were hydrolyzed in $1 \mathrm{~N} \mathrm{HCl}$ at $60^{\circ} \mathrm{C}$ for 5 minutes and later washed several times with distilled water. Two root tips were squashed on each slide and stained with aceto-orcein for 10 minutes. Excess stains were removed, and the edges of the cover slips were sealed as suggested by Grant [32]. The Mitotic index (MI) and the frequency of chromosomal aberration (CA) were calculated for the total number of cells observed with a Nikon Eclipse (E400) light microscope (at 1000× magnification) per slide per water sample for five slides. The mitotic index was calculated as the number of dividing cells, per total number of observed cells, while the frequency of aberrant cells (\%) was calculated based on the number of aberrant cells per total cells scored and number of dividing cells [33].

\section{Data Analysis}

Quantitative data for $\mathrm{pH}$ and other physicochemical parameters were summarized as means \pm standard errors, which were then subjected to Duncan multiple range test and Dunetts test in a one-way ANOVA using SPSS software (version 15.0) for Windows 2007. Significant differences were set at $\mathrm{p} \leq 0.05$.

\section{Results}

Results obtained from the analysis of $\mathrm{pH}$ and heavy metal content after mycofiltration treatment of drinking water samples from six rural communities in Ughelli South Local Government Area in Delta State are presented in Table 1. Most of the water samples were acidic with Okwagbe well water being the most acidic ( $\mathrm{pH}$ of 4.1). Treatment with the mycelium-permeated filter ameliorated all the acidic samples to manageable levels between $\mathrm{pH}$ 6.0-7.1. Likewise, the high amounts of heavy metals found in the water samples were either drastically reduced or totally removed. For instance $\mathrm{Fe}$, which was initially $6.40 \pm 0.03 \mathrm{mg} / \mathrm{l}$ in Iwhreogun River water, was reduced to $0.41 \pm 0.00 \mathrm{mg} / \mathrm{l}$ after mycofiltration. Zinc, manganese, and chromium with initial concentrations of $13.0 \pm 0.4$, $0.23 \pm 0.00$, and $0.10 \pm 0.00 \mathrm{mg} / \mathrm{l}$, respectively in the same water sample, were totally eliminated after mycofiltration.

Statistical data obtained from the microbial examination of the drinking water samples (Table 2) revealed a significant $(p<0.05)$ reduction or complete elimination of total heterotrophic bacteria fungal counts after mycofiltration.

Results of root growth inhibition evaluation of mycofiltrated and non-mycofiltrated drinking water samples are presented in Fig. 2. Compared to the control, the mean root lengths of $A$. cepa grown in mycofiltrated water increased appreciably above root lengths of those grown in nonmycofiltrated water samples. For instance, the mean root length of onion bulbs grown in untreated Esaba borehole water was $3.46 \pm 0.27 \mathrm{~cm}$, while $5.94 \pm 0.10 \mathrm{~cm}$ was recorded in the mycofiltrated sample. Similar trends were observed for all the other test samples.

Results of the cytological evaluation are presented in Table 3. Compared to the control, root tips of onion bulbs exposed to both non-mycofiltrated and mycofiltrated water samples were filled with aberrant cells. The number of aberrant cells decreased while the number of dividing cells and the mitotic indices increased in root tips of onion bulbs grown on the mycofiltrated water samples. For example, the mitotic index in Esaba non-mycofiltrated water sample (7.49 \pm 0.44$)$ increased when the water sample was mycofiltrated $(9.49 \pm 0.49)$. In the same vein, the percentage of aberrant cells decreased from $2.59 \pm 0.83$ in the non-mycofiltrated water to $1.77 \pm 0.80$ in the mycofiltrated water sample. The efficiency was more pronounced in Iwhreogun and Otuwoama water samples with increased mitotic indices of $10.30 \pm 0.55$ and $10.28 \pm 0.44$, respectively, after the treatment comparing favourably with the mitotic index value of $11.39 \pm 0.46$ of the control tap water. 


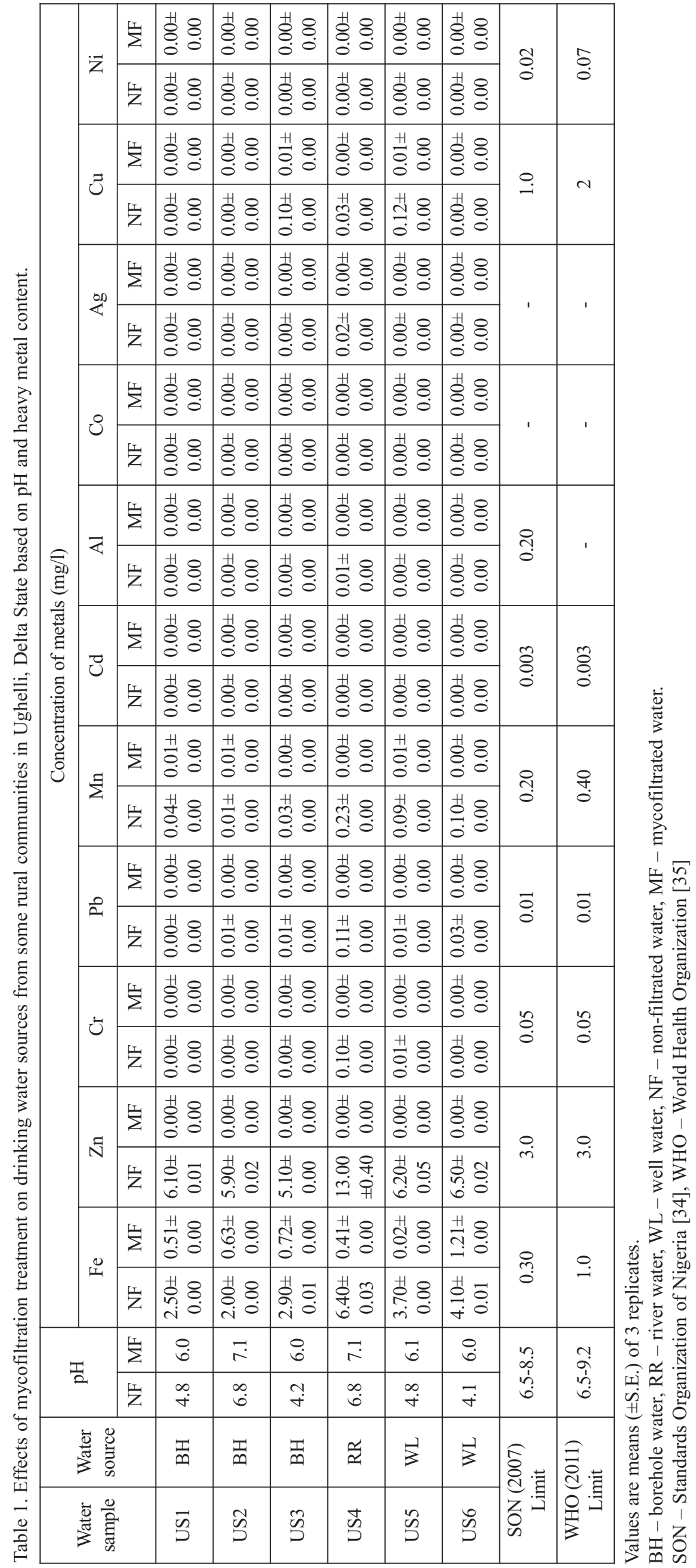


Table 2. Effects of mycofiltration on the microbiological characteristics of drinking water samples in some rural communities in Ughelli South Local Government Area in Delta State.

\begin{tabular}{|c|c|c|c|c|}
\hline $\begin{array}{l}\text { Water } \\
\text { sample }\end{array}$ & $\begin{array}{l}\text { Water } \\
\text { source }\end{array}$ & Treatment & $\begin{array}{l}\text { Total bac- } \\
\text { terial count } \\
(\mathrm{cfu} / \mathrm{ml})\end{array}$ & $\begin{array}{l}\text { Coliform count } \\
(\mathrm{MPN} / 100 \mathrm{ml})\end{array}$ \\
\hline \multirow{2}{*}{ US1 } & \multirow{2}{*}{ Borehole } & Non-filtrated & $18.3 \times 10^{3}$ & $3.2 \times 10^{3}$ \\
\hline & & Mycofiltrated & $0.41 \times 10^{3}$ & - \\
\hline \multirow{2}{*}{ US2 } & \multirow{2}{*}{ Borehole } & Non-filtrated & $23.6 \times 10^{3}$ & $4.36 \times 10^{3}$ \\
\hline & & Mycofiltrated & $4.0 \times 10^{3}$ & - \\
\hline \multirow{2}{*}{ US3 } & \multirow{2}{*}{ Borehole } & Non-filtrated & $23.6 \times 10^{3}$ & $1.4 \times 10^{3}$ \\
\hline & & Mycofiltrated & $0.6 \times 10^{3}$ & - \\
\hline \multirow{2}{*}{ US4 } & \multirow{2}{*}{ River } & Non-filtrated & $1.6 \times 10^{3}$ & - \\
\hline & & Mycofiltrated & - & - \\
\hline \multirow{2}{*}{ US5 } & \multirow{2}{*}{ Well } & Non-filtrated & $38.2 \times 10^{3}$ & $13.4 \times 10^{3}$ \\
\hline & & Mycofiltrated & $5.6 \times 10^{3}$ & $3.2 \times 10^{3}$ \\
\hline \multirow{2}{*}{ US6 } & \multirow{2}{*}{ Well } & Non-filtrated & $26.30 \times 10^{3}$ & $11.6 \times 10^{3}$ \\
\hline & & Mycofiltrated & $5.80 \times 10^{3}$ & $2.0 \times 10^{3}$ \\
\hline
\end{tabular}

\section{Discussion of Results}

A major factor affecting water quality is anthropogenic activities arising from rapid industrialization and urbanization [36]. Results obtained from the physicochemical and microbial analyses of the water samples in this study revealed that the drinking water sources were contaminated to varying degrees with elevated levels of coliform counts and heterotrophic bacteria, some of which could produce toxins. Most of the water samples were acidic and some of the heavy metals in some of the water samples were found at concentrations above national (SON) and international (WHO) regulatory limits.

The effectiveness of the fungus, Pleurotus tuberregium in scavenging heavy metals from aqueous effluents at low $\mathrm{pH}$ and in the economic treatment of $\mathrm{Cd}^{2+}$ and $\mathrm{Se}^{4+}$ ions has been reported $[14,15]$. In a recent report, the fungus Pleurotus florida was used to successfully remove $\mathrm{Pb}^{2+}$ ions from effluents [37]. In a more recent report, Akpaja et al. [38] used the white-rot fungus mycelium-permeated filter to reduce the metallic and cyanide, and bacterial load of cassava effluents. In this study, the mycofilter produced by the fungus Pleurotus tuberregium was effectively used to remove heavy metals from contaminated drinking water sources.

Table 3. Cytological effects of water samples in some rural communities in Ughelli South Local Government Area of Delta State on cells of A. cepa.

\begin{tabular}{|c|c|c|c|c|c|c|c|c|}
\hline \multirow{2}{*}{$\begin{array}{c}\text { Conc. } \\
(\%)\end{array}$} & \multicolumn{4}{|c|}{ Non-filtrated water } & \multicolumn{4}{c|}{ Mycofiltrated water } \\
\cline { 2 - 9 } & $\begin{array}{c}\text { No. of } \\
\text { dividing cells }\end{array}$ & $\begin{array}{c}\text { Total No. of } \\
\text { cells counted }\end{array}$ & $\begin{array}{c}\text { Mitotic index } \\
(\text { Mean } \pm \text { SE) }\end{array}$ & $\begin{array}{c}\% \text { of aberrant } \\
\text { cells }\end{array}$ & $\begin{array}{c}\text { No. of } \\
\text { dividing cells }\end{array}$ & $\begin{array}{c}\text { Total No. of } \\
\text { cells counted }\end{array}$ & $\begin{array}{c}\text { Mitotic index } \\
(\text { Mean } \pm \text { SE) }\end{array}$ & $\begin{array}{c}\% \text { of aberrant } \\
\text { cells }\end{array}$ \\
\hline Control & 240 & 2108 & $11.39 \pm 0.46$ & - & - & - & - & - \\
\hline US1 & 159 & 2123 & $7.49 \pm 0.44$ & $2.59 \pm 0.83$ & 198 & 2087 & $9.49 \pm 0.49$ & $1.77 \pm 0.80$ \\
\hline US2 & 161 & 2296 & $7.01 \pm 0.11$ & $3.02 \pm 0.12$ & 201 & 2092 & $9.61 \pm 0.31$ & $1.51 \pm 0.60$ \\
\hline US3 & 172 & 2161 & $7.96 \pm 0.31$ & $2.67 \pm 0.14$ & 198 & 2002 & $9.89 \pm 0.41$ & $1.36 \pm 0.31$ \\
\hline US4 & 189 & 2067 & $9.14 \pm 0.44$ & $1.60 \pm 0.66$ & 216 & 2097 & $10.30 \pm 0.55$ & $1.24 \pm 0.62$ \\
\hline US5 & 171 & 2043 & $8.37 \pm 0.41$ & $2.25 \pm 0.92$ & 206 & 2004 & $10.28 \pm 0.44$ & $1.50 \pm 0.59$ \\
\hline US6 & 169 & 2053 & $8.23 \pm 0.22$ & $2.94 \pm 0.44$ & 231 & 2307 & $10.01 \pm 0.23$ & $1.42 \pm 0.34$ \\
\hline
\end{tabular}

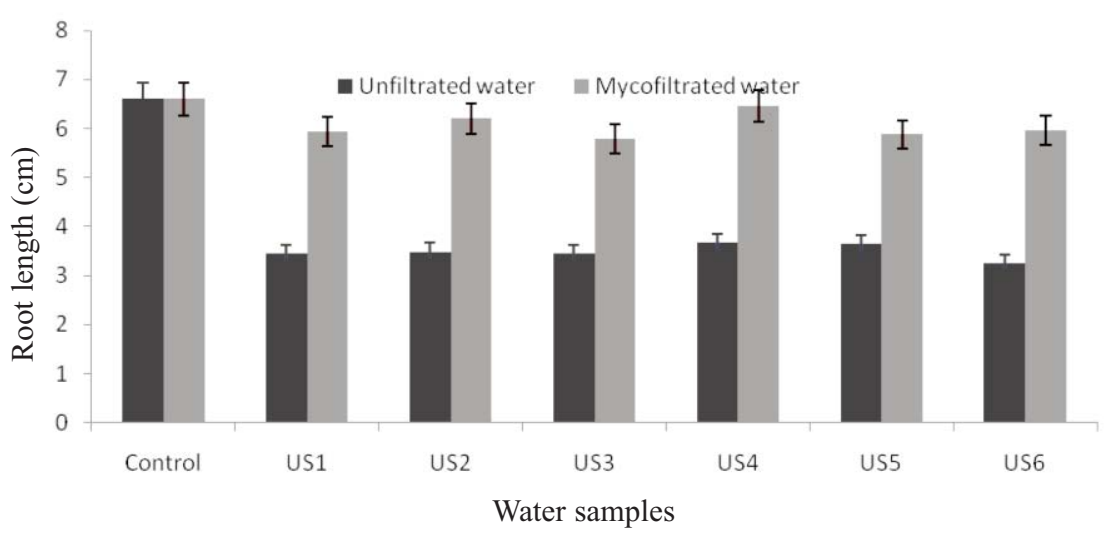

Fig. 2. Mean root length $(\mathrm{cm})$ of $A$. cepa roots exposed to non-mycofiltrated and mycofiltrated water samples in some rural communities in Ughelli South Local Government Area of Delta State (US1 - Esaba, US2 - Ophorigbala, US3 - Owahwa, US4 - Iwhreogun, US5 - Otuwoama, and US6 - Okwagbe). 
The use of Allium cepa as a plant bioindicator of cytogenotoxicity in drinking water has been exploited in previous studies in Nigeria [23-26]. In this study, two aspects of toxicity were examined: general toxicity estimated by the inhibition of the growth of root bundles (macroscopic evaluation) and cyto-genotoxicity assessed by microscopic evaluation of alteration in the mitotic index and chromosome structure of the meristematic root tip cells (microscopic evaluation). Our study showed that, compared with the control, the non-mycofiltrated and mycofiltrated water samples were characterized significantly with poor root growth. However, data obtained for the macroscopic evaluation in the mycofiltrated water samples were much closer to those obtained for the control (tap water). Furthermore, unlike the mycofiltrated water samples, the non-mycofiltrated water samples induced root malformations (data not shown). The malformations were mostly twists and root tips bent upward, resembling hooks that can cause genetic defects, either somatic or inherited [39].

There was a linear relationship between the macroscopic and microscopic parameters for all the drinking water samples examined. In A. cepa, whenever there is root growth inhibition, there is always a reduction in the number of dividing cells, a phenomenon attributable to the effects of environmental chemicals acting singly or in their combined states to induce genetic abnormalities in biological systems [40,41]. Our study showed that, compared with the control, the non-mycofiltrated and mycofiltrated water samples were characterized appreciably by a lower number of dividing cells and a higher percentage of aberrant cells. However, unlike values for the non-mycofiltrated water samples, values obtained for these cyto-genotoxic parameters in the mycofiltrated water samples were much closer to data obtained for the control (tap water).

\section{Conclusions}

1. The present study utilized physicochemical analysis in combination with the Allium cepa cyto-genotoxic bioassay to evaluate the efficiency of mycofiltration for the reduction/total elimination of toxic components of drinking water samples in some rural communities in Ughelli South Local Government Area in the Niger Delta region of Nigeria.

2. Results obtained revealed that the Allium test showed excellent correlation with data obtained from physicochemical and microbial analyses, a strong indication that the bioassay served as a perfect monitoring system for the detection of environmental chemicals that may pose a genetic hazards in living organisms.

3. This study has further validated the use of mycofiltration as a self-help and low-cost technology for first-tier bioremediation of contaminated drinking water. Large amounts of agricultural wastes, including maize cobs generated from farms in these rural communities, could be used as substrates in a low-cost and efficient cultivation method for the production of fungal filtration membranes to ameliorate the contaminated drinking water.

\section{References}

1. ORUBU C.O. Water resources, environment and sustainable development in Nigeria. J. Hum. Ecol. 19, (3), 169, 2006.

2. AYANTOBO O.O., OLUWASANYA G.O., IDOWU O.A., ERUOLA A.O. Water Quality Evaluation of Hand-dug Wells in Ibadan, Oyo State, Nigeria. Hydrology for Disaster Management: Special Publication of the Nigerian Association of Hydrological Sciences pp. 231-23, 2012.

3. GALADIMAA., GARBA Z.N., LEKE L., ALMUSTAPHA M.N., ADAM I.K. Domestic water pollution among local communities in Nigeria - Causes and consequences. Eur. J. Sci. Res. 52, (4), 592, 2011.

4. OHWO O., ABOTUTU A. Access to potable water supply in Nigerian cities: Evidence from Yenagoa metropolis. Amer. J. Water Res. 2, (2), 31, 2014.

5. MUTA'AHELLANDENDU J. Health implications of water scarcity in Nigeria. Eur. Sci. J. 8, (18), 111, 2012.

6. EKONG F., JACOB A., EBONG S. Water resource management in the Niger Delta region of Nigeria: The role of physical planning. Int. Rev. Soc. Sci. Human 3, (1), 51, 2012.

7. EFE S.I., MOGBORUKOR J.O.A. Acid rain in Niger Delta region: Implication on water resources quality and crisis. AFRREV STECH, 1, (1), 17, 2012.

8. AJAYI D.D., OKUNOLA R.A., AIYEDE E.R. Liquefied natural gas (LNG), environment and the society. E3 J. Environ. Res. Manage. 3, (6), 114, 2012.

9. EFE S.I. Spatial variation in acid and some heavy metal composition of rainwater harvesting in the oil producing region of Nigeria. Nat. Hazard 5, 307, 2010.

10. EGBAI J.C., ADAIKPOH E.O., AIGBOGUN C.O. Water quality assessment of groundwater in Okwuagbe community of Delta State Nigeria. Tech. J. Eng. Appl. Sci. 3, (19), 2347, 2013.

11. BRIGGS A. Determining of ethanolamine, ethylene glycol and triethylene glycol by ion chromatography for laboratory and field biodegradation studies. J. Environ. Monitor 5, 336, 2006.

12. STAMETS P. Mycelium Running: How Mushrooms Can Help Save the World. Tenspeed Press, Berkeley, Toronto. pp. 54-64, 2005.

13. ROBLES-HERNANDEZ L., GONZÀLEZ-FRANCO A.C., CRAWFORD D.L., CHUN W.W.C. Review of environmental organo-pollutant degradation by white-rot basidiomycetes mushrooms. Tecnociencia Chihuahua 2, (1), 32, 2008.

14. OKUO J.M., AKPAJA E.O., EGUONO W.O. Kinetics of cadmium (II) and selenium (IV) ions removal from aqueous solution by the fruiting bodies of white-rot fungi (Pleurotus tuberregium). J. Chem. Soc. Nig. 33, (1), 56, 2008.

15. OKUO J.M., AKPAJA E.O., IYELENMEHOLO A. Biosorption of cadmium (II) and selenium (IV) ions from aqueous solution by sclerotia of Pleurotus tuberregium (Fr.) Singer. Int. J. Chem. 1, (1), 47, 2009.

16. WORLD HEALTH ORGANISATION (WHO) Surveillance of drinking-water quality. Geneva, World Health Organization. Available at:

http://whqlibdoc.who.int/monograph/WHO_MONO 63. pdf. 1976. [Accessed Feb 1, 2012].

17. ARKHIPCHUK V.V., MALINOVSKAYA M.V., GARANKO N.N. Cytogenetic study of organic and inorganic toxic substances on Allium cepa, Lactuca sativa and Hydra attenuate cells. Environ. Toxicol. 15, 338, 2000.

18. FISKESJÖ G. The Allium test - an alternative in environmental studies: the relative toxicity of metal ions. Mutat. Res. 197, (2), 243, 1988. 
19. MA T.H. The international program on plant bioassays and the report of the follow-up study after the hands-on workshop in China. Mutat Res 426, 103, 1999.

20. FIRBAS P., AMON T. Allium chromosome aberration test for evaluation effect of cleaning municipal water with Constructed Wetland (CW) in Sveti Tomaž, Slovenia. J. Bioremed. Biodeg. 4, 189, 2013.

21. BARBÉRIO A. Bioassays with plants in the monitoring of water quality. In: Elshorbagy W, Chowdhury RK editors. Water Treatment. Rijeka, Croatia: InTech, pp. 317-334. Available at: http://dx.doi.org/10.5772/2883 2013 [accessed 09 October 2014]

22. GRANT W.F. The present status of higher plant bioassays for the detection of environmental mutagens. Mutat. Res. 310, 175, 1994.

23. OLORUNFEMI D.I., OSARETIN O.I. In situ assessment of genotoxic hazards of selected hand-dug well water samples in Uhunwonde Local Government Area of Edo State. Nig. J. Appl. Sci. 30, 150, 2012.

24. OLORUNFEMI D.I., OFOMATA C.R., ALIMBA C.G. Cytogenotoxicity assessment of a University borehole water supply using the Allium cepa test. J. Sci. Res. Dev. 14, 25, 2013.

25. OLORUNFEMI O.P., CHIGOZIE M., OLORUNFEMI D.I. Genotoxicity of contaminated drinking water sources detected by a plant bioassay. Being a paper presented at the $24^{\text {th }}$ Annual Meeting of the Society of Environmental Toxicology and Chemistry (SETAC) Europe Congress Centre, Basel MCH Messe Schweiz (Basel) AG, Messeplatz, Basel, Switzerland. $11^{\text {th }}-15^{\text {th }}$ May, 2014.

26. OLORUNFEMI1 D.I., OLORUNFEMI O.P., AGBOZU I.E. Genotoxicity assessment of contaminated drinking water sources in a rural community in Edo State of Nigeria. J. Geosci. Environ. Protect. 2, 52, 2014.

27. CLAAASEN H.C. Guidelines and Techniques for Obtaining Water Samples that Accurately Represent the Quality of an Aquifer. US Geological Survey Open File Report 82-1024. pp. 49, 1982.

28. BARCELONA M., GIBB J.P., HELFRICH J.A., GARSKE E.E. Practical Guide for Groundwater Sampling. Ilinois State Water Survey ISWS Contract Report 374, Illinois. 103p. Available at:

http://www.epa.gov/OUST/cat/pracgw.pdf 1985, [accessed 09 October 2014].
29. AMERICAN PUBLIC HEALTH ASSOCIATION (APHA). Standard Methods for the Examination of Water and Wastewater $21^{\text {st }}$ ed. Washington DC: American Public Health Association 1220 p. 2005.

30. UNITED STATES ENVIRONMENTAL PROTECTION AGENCY (USEPA). National Recommended Water Quality Criteria-Correction: EPA 822/Z-99-001. Washington DC: USEPA, 1996.

31. FISKESJÓ G. The Allium test as a standard in environmental monitoring. Hereditas 102, 99, 1985.

32. GRANT W.F. Chromosome aberration assays in Allium. A report of the United States Environmental Protection Agency Gene Toxicity Program. Mutat. Res. 99, 273, 1982.

33. OLORUNFEMI D.I., OMO-ATAGA S.O., Ofomata R.C. Studies on the physicochemical properties and genotoxicity of effluents from a dairy industry. Bayero J. Pure Appl. Sci. 5, (2), 11, 2012.

34. STANDARD ORGANISATION OF NIGERIA (SON). Nigerian Standard for Drinking Water Quality. Lome Street, Abuja, Nigeria. pp. 29, 2007.

35. WORLD HEALTH ORGANIZATION (WHO). Guidelines for Drinking Water Quality $4^{\text {th }}$ ed. Geneva: World Health Organization. pp. 564, 2011.

36. UBALUA O.A., EZERONYE O.U. Nutrients and selected physico-chemical analysis in the Aba rivers surface waters Abia State, Nigeria. Environ. Ecol. 23, (1), 141, 2005.

37. PRASAD A.S.A., VARATHARAJU G., ANUSHRI C., DHIVYASREE S. Biosorption of lead by Pleurotus florida and Trichoderma viride. Brit. Biotechnol. J. 3, (1), 66, 2013.

38. AKPAJA E.O., KESIENA C.G., OKHUOYA J.A. Mycofiltration potential of Pleurotus florida (Mont.) Singer on cassava mill effluent. Biol. Environ. Sci. J. Trop. (BEST) 11, (3),191, 2014.

39. SWIERENGA S. H., HEDDlE J. A., SIGAL E. A., GILMAN J. P., BRILLINGER R. I., DOUGLAS G. R., NESTMANN E. R. Chromosome aberrations and sister chromatid exchange in Chinese hamster ovary. Mutat. Res. 626, 4, 1991.

40. KONG M.S., MA T.H. Genotoxicity of contaminated soil and shallow well water detected by plant bioassays. Mutat. Res. 426, 221, 1999.

41. BABATUNDE B.B., BAKARE A.A. Genotoxicity screening of wastewaters from Agbara Industrial Estate, Nigeria evaluated with the Allium test. Poll. Res. 25, (2), 227, 2006. 